\title{
Negotiation of Female Information Integration in Choosing Leaders (Case Study of Information Integration of Muslimat NU in Choosing Khofifah Indar Parawangsa as Governor of East Java in Magetan)
}

\author{
Fitri Pangastuti; Prihastiwi Utari; Agung Satyawan \\ Sebelas Maret University, Indonesia \\ http://dx.doi.org/10.18415/ijmmu.v8i3.2396
}

\begin{abstract}
Politics and women are the main discourse now never ending. Politics as an instrument for recruiting leaders must deal with various factors, including from a religious perspective. Among the jurists, it is almost agreed that a woman is not allowed or prohibited to become a head of state, because she is identical to an imam or caliph. The prohibition of women from becoming heads of state is a hadith narrated by Imam Bukhari from Abu Bakrah; Prophet SAW. said when he heard that the Persians adopted the daughter Kisra after her death as ruler. "It will never be fortunate for a people to hand over their power (government) to a woman". Islamic Sharia is very clearly stated in the Al Quran. Islam does not allow public leadership, such as: president, governor, regent or the like are held by women based on various arguments mentioned in the Qur'an and sunnah including the letter an Nisa which means "Men are men. is a leader for women? ". The above argument strongly emphasizes that women do not have the slightest opportunity as leaders, even within the scope of regional heads. In addition, the identity of women's communication in politics is still based on the stigma of ascribed status not because of Achievement status. However, the election of Khofifah Indar Parawangsa, whose knowledge is that she is a woman is contrary to this argument. In fact, he was able to be elected Governor of East Java and was able to be accepted by Muslimat NU, especially in the Magetan area. This makes the author want to further investigate the phenomenon that occurs. The research was conducted using qualitative research, namely research procedures that produce descriptive data in the form of words written or spoken from people and observable behavior. According to the research, it was found that in the negotiation of women's information integration in choosing leaders, there were valence and assessment weights.
\end{abstract}

Keywords: Information Negotiation; Valence; Weight of Assessment;Muslimat NU; Election of Governor

\section{Introduction}

Identity of women's communication in politics is still based on the stigma ascribed status not because of achievement status. It can be interpreted that in the election, the voters to make their choice do not see their abilities but based on the side of the family tree. For example: in the Purwakarta regional election the voters did not see the skills of Anne Ratna Mustika but because she was the wife of the 
former Purwakarta regent (Dedi Mulyadi). Even though Anne's background was once Mojang Kah. Purwakarta in 2001 and represented Kah. Purwakarta in Pasanggiri Mojang Jajaka, West Java 2001. Could be proof if he also has abilities that can be considered.

Another example is the elected Sragen regent Kusdinar Untung Yuni Sukowat who is usually called Yuni. He is the biological son of Untung Wiyono, the Regent of Sragen for two periods (20012011). During his tenure, Untung partnered with Agus Fatchurrahman as regent and deputy regent. In 2011, Yuni ran as a candidate for regent from the PDI Perjuangan but was defeated by Agus, who ran from the Golkar Party. In this Pilkada, it was Yuni's turn to win. Some time ago Yuni was fired from the PDI-P membership for running as a candidate for regional head from another party. The correlation of family relationships is still very strong in the pilkada with female leader candidates. Whereas what is prioritized in choosing prospective leaders is not only based on the ascribed status but also the achievements of the female leaders.

On a national scale, according to data reported by the conersation.com, the third round of simultaneous regional head elections (pilkada) held on 27 June 2018 showed an increase in the electability of women as local political leaders. Of the total number of 94 women who competed in the political party, 31 of them were successfully elected, namely (32.98\%). This figure is almost $2 \%$ superior to the regional elections which were also held simultaneously during the previous year. According to KPU data documentation, overall women won 31 out of a total of 338 opportunities for regional head and deputy regional head political positions, or equal to $(9.17 \%)$.

Meanwhile, for the position of governor, there are only two women who are candidates. Five female candidates competed as candidates for deputy governor. This data shows that women's participation in the Pilkada arena is not evenly distributed across the three levels of regional government. However, the results of the 2018 pilkada prove that although women rarely become candidates for governor and deputy governor, they are very effective in gaining votes. The electability of women as governors reaches $50 \%$. This was due to the victory of the Khofifah Indar Parawansa-Emil Elestianto Dardak pair in East Java, which collected $53.55 \%$ of valid votes with a difference of 1 million votes from the pair Saifullah Yusuf-Puti Guntur Soekarno. Women have proven successful in gaining the position of deputy governor with an electability rate of $40 \%$. Women running as candidates for deputy mayor also showed a significant success rate, namely 37.5 percent. The lowest electability occurs at the city government level, where only a quarter of female candidates have won (theconversation.com, 2018).

In the discourse of the existence of female leadership, the victory of Khofifah-Emil Dardak has further strengthened efforts to mainstream gender in politics. From a series of regional elections (Pilkada) held in 2018, 16 female pairs were selected as winners of the political contestation. The research results indicate that women candidates for mayor and deputy mayor are more likely to retain their seats than those who are incumbent and try to continue the term of office of regents and deputy regents.

In addition, the background distribution shows the potential for legislative members to be elected to the executive branch. Political and social capital while sitting in parliament can increase women's chances of becoming regional heads. Of the 16 women elected to be mayors, regents and governors, 6 of them were incumbents; Mundjidah Wahab (Regent of Jombang), Ade Uu Sukaesih (Mayor of Banjar), Umi Azizah (Regent of Tegal), Puput Tantriana Sari (Regent of Probolinggo), Iti Octavia Jayabaya (Regent of Lebak), and Tatong Bara (Mayor of Kotamobagu). part of the political dynasty including Anne Ratna Mustika (Regent of Purwakarta) who was the wife of the former Purwakarta Regent Dedi Mulyadi and Erlina (Regent of Mempawah), the wife of the Deputy Governor of West Kalimantan Ria Norsan. 
Table of Women's Candidacy and Election in the 2018 Pilkada

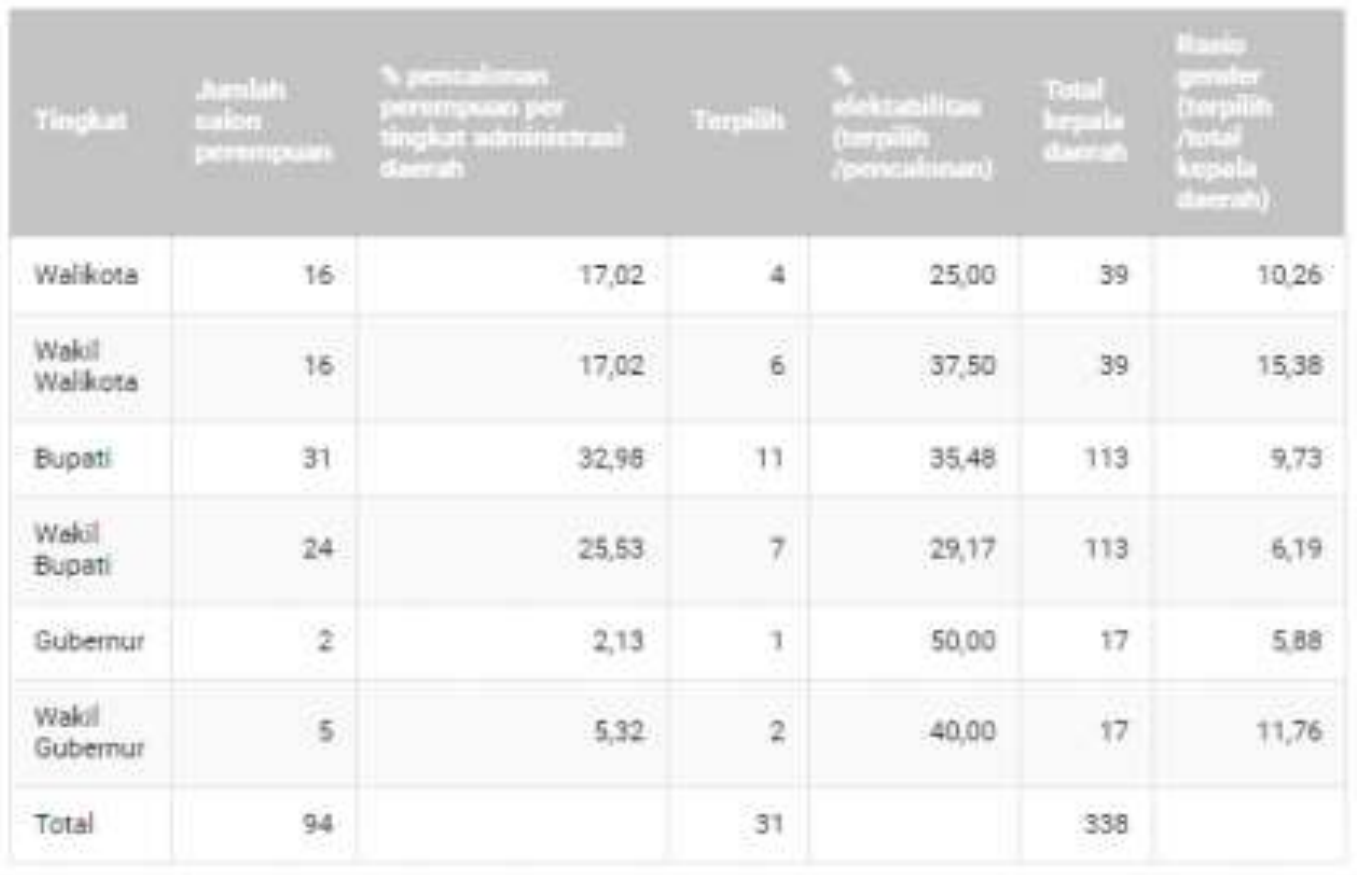

The table was processed by Ella S. Prihatini, Endeavor scholar and PhD candidate from, University of Western Australia. In his article on thepage theconversation.com with the title Women's Electability in the 2018 post-conflict local election, it increased (theconversation.com, 2018). Various records from the results of the 2018 Pilkada show that women's electability continues to increase even though the pace is not too fast. This increase is a positive indication for women's representation as political leaders at the local level. With the increasingly significant authority of local governments in determining policies, women who become regional heads are expected to strengthen the echo of gender mainstreaming. Substantive representation like this will be the biggest test for women leaders, the results of which can be seen, among other things, from the decrease in inequality in school enrollment rates between boys and girls and the budget for health, which has an increasingly significant portion. The results listed in the table above provide evidence of how the electability of women in the context of elections to regions has increased. The public also appears to be open to accepting the figure of women as their political leaders.

The selection of regional leaders for the province of East Java has been completed, and the pair Khofifah Indar Parawansa - Emil Elastianto Dardak was elected as Governor-Deputy Governor for the 2018-2023 term. The pair managed to outperform their rival, Syaifullah Yusuf-Puti Guntur Soekarno, who could be said to be an incumbent. In the 2018 East Java gubernatorial election, the first pair of Khofifah Indar Parawansa (Khofifah) - Emil Elestianto Dardak (Emil Dardak) was promoted by 5 political parties, namely the Hanura Party, the United Development Party (PPP), the Democratic Party, the National Democratic Party (Nasdem) and the Party Group of Work (Golkar). Meanwhile the pair Saifullah Yusuf (Gus Ipul) -Puti Guntur Soekarno (Puti) are supported by 4 political parties, namely the Prosperous Justice Party (PKS), the Great Indonesia Movement Party (GERINDRA), the Indonesian Democratic Party of Struggle (PDIP) and the National Awakening Party ( PKB).

The General Election Commission of East Java province on July 72019 has determined the winner in the 2018 East Java Governor-Deputy Governor Election, namely the Khofifah Indar Parawansa - Emil Elastianto Dardak pair, ahead of the Syaifullah Yusuf - Puti Guntur Soekarno pair. The description of the vote acquisition between the pairs of candidates for governor Khofifah-Emil, promoted by the 
Golkar, Hanura, Democrat, PPP, PAN and Nasdem parties, received 10,465,218 votes or 53.55 percent. Meanwhile, the pair Saifullah Yusuf-Puti Guntur Soekarno who was promoted by PDIP, PKB, PKS, and GERINDRA received 9,076,014 votes or 46.5 percent (cnnindonesia.com, 2018). According to the head of the East Java KPU, Eko Sasmito, the total votes coming from 38 districts / cities throughout East Java were $20,323,259$. Of that number, 19,541,232 votes were declared valid, while 782,027 votes were declared invalid. The difference is around one million votes, or nearly 7 percent (cnnindonesia.com).

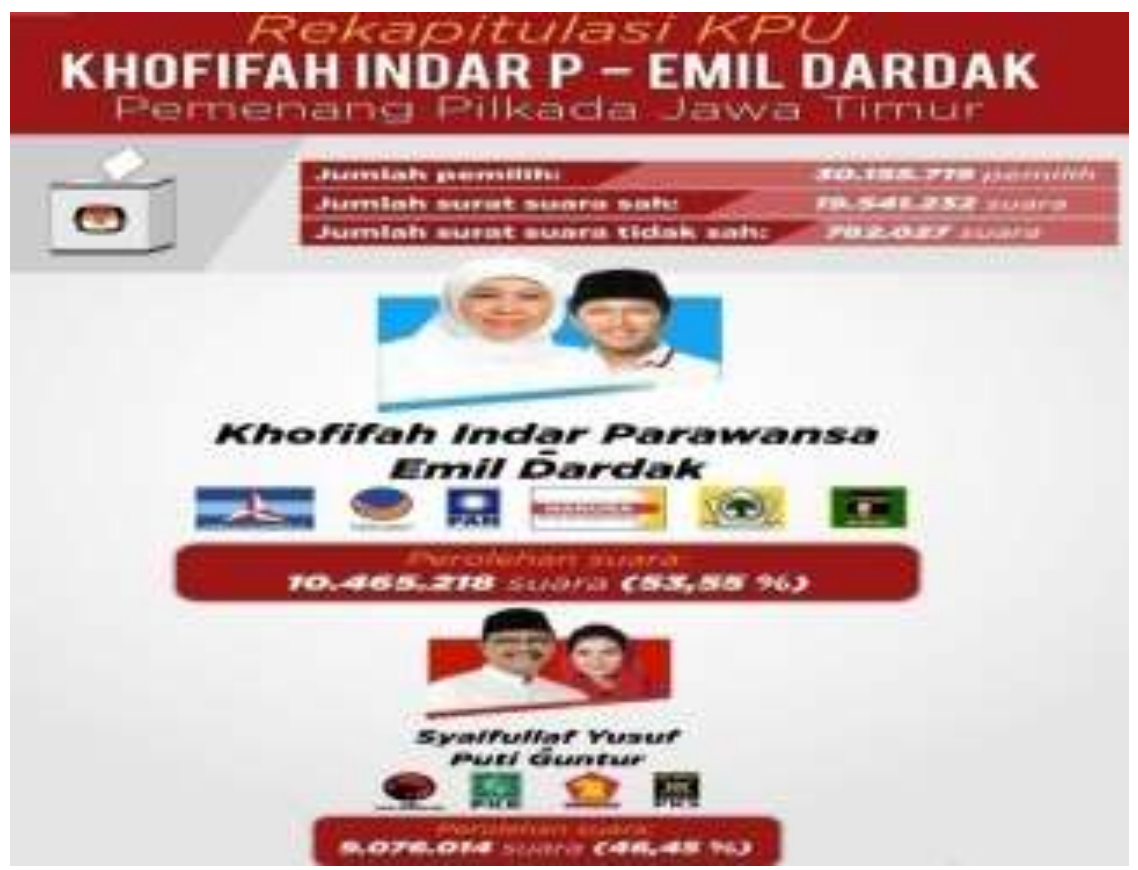

\section{Infographics of the 2018 East Java Governor Election Recapitulation (Source: kompas.com)}

From this calculation the Khofifah-Emil pair appear to have narrowly won over the SyaifulahPuti pair, even though from the PDI-P internal survey the potential for Syaifulah-Puti's victory is very high. This result was beyond the expectations of Syaifulah-Puti because their vote pockets were spread almost evenly to all regions in East Java. In Magetan district alone, their internal survey still grants thepair incumbent. According to observers, there were several factors that became the " dark horse " determining the victory of the Khififah-Emil pair, namely the representation of Khofifah as the general chairman of Muslimat NU, an organization for NU women. If this did happen, it would be interesting that Magetan is generally the home of the PDIP, the main party supporting the pair Syaifulah Yusuf-Puti Guntur. Facing the issue of Muslimat NU members in Magetan Regency, they continue to encourage the chances of winning the East Java Cagub number 1, Khofifah Indar Parawansa (surabaya.tribunnews.com, 2018). In this context, Muslimat NU is actively involved in political campaign activities in the Magetan region, which essentially reflects events of political communication.

Political parties and their wing organizations, in carrying out their function as a means of political communication, should be able to accommodate various forms of interest and articulation of the aspirations of cadres and society, in this case especially women. How political parties and their underbows open themselves in providing opportunities for women to participate in political communication. At the minimum point for fellow female cadres and to voice carefully the interests of women.

The urgency of political communication by involving women to participate more in decisionmaking or joining the government or entering the political sphere is not merely to increase women's participation. Moreover, it is hoped that women's representation in policy-making can voice women's own 
aspirations and interests, not only to fulfill quotas, but to actually carry out their functions properly. From the root of the political journey, women should be thoroughly involved in the process. As stated by Rush and Althoff, political communication plays a very important role in a political system. He plays a dynamic element, and is a decisive part of the process of political socialization, political participation, and political recruitment (Muhtadi, 2008). Openness to political communication can influence people to be actively involved in politics on the one hand, and on the other hand, political communication can also suppress political participation (Nimmo, 2004).

It is at this point that the Muslimat NU in Magetan district plays itself as an actor ofcommunication politicalas declared by forming a campaign team from the Muslimat NU element. The construction that has so far been taking place is the thought of separating as if religion was only an ubudiyah affair, while other problems, such as health, economy, and education, which affect the overall quality of life are also religious issues. The two cannot be separated. How to concoct it properly to be conveyed to the congregation, the Muslimat NU preachers certainly understand well (Niiam, 2019). Muslimat NU has proven itself to be a pillar of teachers for NU by taking concrete actions to overcome various problems. They have carried out religious orders which previously were only voiced from stage to stage, into repeated rhetoric without real action that resulted in changes in society. Included in this context is the role of Muslimat NU members in their political movements to participate in the sociopolitical work of selecting regional and national leadership.

\section{Problem Formulation}

1. How is the negotiation of information on Muslimat NU in Magetan Regency in choosing Khofifah Indar Parawansa as Governor of East Java?

\section{Theoretical Basis}

In the dynamic political movement in Magetan Regency regarding the selection of regional leaders (in this case, the election of the governor / deputy governor of East Java), Muslimat NU participated in the political process. Muslimat NU supports the Khofifah-Emil pair, by conducting a political campaign for the couple (surabaya.tribunnews.com, 2018). Magetan Regency election, because there was the smallest difference between the pair Gus Ipul-Putty (188,988 votes) and Khififah-Emil $(189,442)$, among other districts in East Java (KPUD East Java).

Furthermore, in the perspective of communication science, the above reality can be explained using information integration theory. This happens because various information about the candidate for governor Khofifah is a very potential source to influence communicants / constituents in determining their political attitudes. According to Littlejohn \& Foss, 2009, the effect of changing a person's attitude depends on two things, namely: (1) Valence and purpose. This dimension explains the extent to which information supports what a person already believes. Information that supports the beliefs that have been in a person before can be said to be positive information, and (2) the weight of the assessment. This dimension relates to the credibility of information. This means that if someone considers information as truth, then that person will give a high assessment of the information. Conversely, if someone considers an information to be a mistake, then that person will give a low judgment.

The Khofifah phenomenon becomes interesting to examine with this theory because with the valence that Khofifah is positively informed which supports one's belief. On the other hand, there is a strengthening of the weight of the assessment which sees that if the information about Khofifah is correct, then the constituents will give more weight to the assessment. 
In the process of integrating the information, there is a gap between the valence and weight of the khofifah's assessment as a female leader. From the values of religion, gender, and local culture the majority do not allow women as leaders. However, through the weight of his assessment, khofifah can be accepted as a governor, which is a strategic position. This creates gaps between the two. Therefore, negotiations are needed within Muslimat NU Magetan both individually and in groups. According to Swann (2005: 78), through a negotiation process, a person shows that the making of truths of thought will be understood as an interactive process in which the person and others form thoughts of each other. This negotiation process aims at how a person positions his or her identity so that other people can accept what it is.

\section{Method}

This research uses qualitative research, namely research procedures that produce descriptive data in the form of written or spoken words from people and observable behavior (Bogdan \& Tylor 1992). Qualitative research deals with the ideas, perceptions, opinions, or beliefs of the person being studied, all of which cannot be measured in numbers. Qualitative research aims to obtain a complete picture of something according to the human perspective being studied. In qualitative research, the researcher is the main research tool, the researcher has more advantages than the questionnaire commonly used in quantitative research. Therefore, the sequence of activities can change at any time depending on the condition and the number of symptoms found. This approach is directed at the setting and the individual as a whole.

This research design is of a qualitative type. This research is a research procedure that produces descriptive data that contains the writings or words and behavior of theresearch produces people being observed. Thisin-depth descriptions in a particular setting and context that is studied from a complete, comprehensive and holistic point of view (Bogdan \& Tylor 1992). In qualitative research, the researcher is not isolated, but lies in the world he is researching, in which interpretation is very important. Qualitative researchers conduct studies on natural subjects, as they are, through strong interpretive abilities. Qualitative researchers make efforts to interpret a phenomenon which is the subject matter in the research. According to Strauss \& Corbin, this type of research produces findings without statistical or quantitative procedures (Snape, D \& Spencer, L. 2003).

There are several things that stand out in this descriptive type of research, as explained by Neuman as follows: (1) Producing a detailed and accurate picture, (2) Producing new data that is different from before, (3) Producing a series of categories or type classifications, (4) Explaining the stages or setting, (5) Documenting the mechanism of the causal process, (6) Reporting the research background or context of the situation (Neuman, WL 2003). This research strives to fulfill the above-mentioned research features.

\section{A. Dimensions of Valence}

This dimension relates to an individual's assessment of whether the information is good news or bad news. Whether the news is good or bad depends on one's attitude and beliefs. The valence dimension, in this study, will be described in the following descriptions:

\section{A.1. Informants' Assessment of the Nomination of Khofifah-Emil as Governor of East Java based on the value of Religion}

The informant's assessment of the candidacy of the Khofifah-Emil pair received various responses from the informants. One of the informants in this study, for example, said that information or news about the candidacy of Khofifah - Emil was still acceptable among NU Muslims even though it was contrary to the religious values stated in the letter an Nisa verse 34 which implied that the leader must be 
male. This informant is the head of the Muslimat branch of NU Magetan, Hj Isnaini, who sees the information regarding the nomination as an acceptable reality for himself and his group, a sign that Khofifah has opened up opportunities as a woman to lead the East Java Province. The informant further said:

“... the information is encouraging, the candidacy is positive to fill a democratic party at the provincial level ... Khofifah is the Chairman of our Muslimat NU, even though she is a woman who in fact implies that the leader must be a man like which is stated in the Al-Quran letter An-Nisa verse 34. But he was able to become Chairman of Muslimat NU and there is a belief that he can lead East Java ... so the information is positive ... " (Isnaini, 2019)

The informant in the above statement said how the news about the nomination of Khofifah - Emil as a candidate for governor of East Java is a happy reality, especially when he relates to the position and meaning of Khofifah in the management structure of organizations such as Muslimat NU. According to informants, the information on the nomination was a breath of fresh air for a change in leadership in East Java, so it was greeted with joy and a positive feeling. This, of course, especially happened to the Muslimat NU, especially Magetan.

"... actually it's been a long time sis, we from the NU community have heard about the nomination for the Governor of East Java ... yes, Gus Ipul is an NU person too ... Khofifah NU, the General Chairperson of Muslimat NU instead ... yes this is in the end a matter of choice ... but that information about Khofifah's candidacy - Emil is positive information, which is also proud if in my opinion, even though she is a woman and her religion implies that the leader is a man, she is able to prove if her abilities not inferior to men, and I believe he deserves to be the governor of East Java ", you know for yourself, khofifah has served as a minister, chairman of the Muslimat NU so there is no reason not to support him (Sudarto, 2019).

From the above expression, it can be seen that nomination information within NU's internal circles is a positive thing, is considered a form of good information and is seen as being able to elevate NU circles as a proud reality. However, Khofifah is a cadre of NU, who in the political context this time is within the NU wing organization, namely Muslimat NU. Sudarto also said there was an additional option, because the information about the elimination of Khofifah also got NU rivals, namely Gus Ipul / Syaifulah Yusuf.

The problem that was then faced was not about Khofifah or Gus Ipul. According to Sudarto, the positive information provided input for constituent communities in determining their choice. There are advantages to each candidate, which in this case becomes the personal area of Muslimat NU members to make their own choices or determine their political stance in the democratic party in East Java. According to Sudarto, the information that Gus Ipul and Khofifah were both running for the governorship election this time was a fact that did not need to be contested with the stance that sparked conflict. Because it was just an option, choosing Gus Ipun Bai and choosing Khofifah was also good. The next discussion is to look at leadership from an Islamic perspective. This perspective is an interesting point of view, and it is so attractive that it has a very strong opportunity for tug of war to occur. Researchers will confirm to the structure of the Muslimat organization NU and its staff and members. In the view of the Head of the Muslimat Branch of NU, Magetan Regency, Isnaini, the issue of the Islamic religious view of women's leadership actually has different perspectives on the ulemas. Some see that what is meant in religion is more to non-government. The informant also said that women thinkers from NU saw gender equality in political recruitment as important. Isnaini said:

“... if women have to lead, because the number of votes that do win, it's not because of the number itself ... there are qualities that are certainly a consideration ... NU female figures have long been 
voicing gender justice. .. even Mrs. Khofifah also wrote down her thoughts through a book, sis ... "(Isnaini, 2019).

As a Muslimat NU figure, the informant saw that religion actually provided gender justice in this case, because female government leaders were not based on gender, but on thoughts and abilities. Isnaini also refers to Khofifah's own thoughts which were successfully recorded and published. Before joining the democratic party in 2018, Khofifah's thoughts enlivened the discourse on women's leadership. In the book "NU, Women, Indonesia, Traditional Islamic Perspectives", Khofifah emphasized the need for NU women to spread out and engage in various professions in the public sphere to help solve problems faced by the Indonesian nation. Khofifah gave an example that NU women need to become doctors, to overcome the problem of the high maternal mortality rate (MMR) and under-five in Indonesia. (Parawansa, 2015). Khofifah also thought that women deserve to be leaders. In the book "Leading to Serve", Khofifah emphasized that with the diverse backgrounds in Indonesia, men and women have the same rights and opportunities to become leaders at the local and national levels. Openness and support from various parties, including organizational leaders and community leaders are needed to encourage women to become leaders (Parawansa, 2015). Furthermore, PC NU Magetan secretary, Sudarto, saw thatleadership women's in government was a necessity. She admitted that even though she had different choices about the political event, women leaders in government were no longer seen from "because she was a woman", more than that as personal capability. He further stated as follows:

"... the people or the people of NU, in my opinion, do not see this as something that should be argued about ... the problem has been resolved ... then what is being considered is the capacity concerned" (Sudarto, 2019).

The conception of equal rights for women in political movements, which is marked by the absence of arguments in the attitudes as stated by the informant above, at a theoretical level, can be seen from the thoughts of Prof. Dr. Musdah Mulia. Thoughts on formal politics of Musdah Mulia can be found in the book "Women and Politics". Musdah Mulia considers that women should enter formal politics by bringing a new color, because women interpret power differently from men. Power by women, namely power with love and tenderness, can be directed to achieve common goals. So women can become politicians who do not hurt their political opponents, are able to hone their maternal side to be responsive to the needs of others, and empower others (Mulia, 2005: 12-13).

Men and women are equal beings, women can be leaders, and Islam guarantees women's political rights. Mulia provides solutions to increase women's political participation, namely through dismantling myths that hinder women's political participation, criticizing gender-biased interpretations of religion and overcoming barriers to a more gender-just understanding of religion, as well as trying to change unfair public policies (Mulia, 2005). If we trace it, the Nadliyin circles actually openness to the possibility of women leaders in government cannot be separated from the dynamic efforts of the first Bahsul Masa'il (I) in the city of Salatiga. At that time the role of women in politics, for example, the village head was not allowed. The scholars used themethod istinbat qauli or those who were strongly guided by the classical ulama's mindset at that time which was understood textually.

\section{A.2 Evaluation of Informants Regarding the Nomination of Khofifah-Emil as Governor of East Java based on Gender values}

Khofifah who is a woman continues to receive support from NU Muslims. This shows that gender values do not have a negative effect in making decisions. For East Java, it will be seen from the opinion of the Muslimat NU internal circles in Magetan district, as the area where this research was held. 
According to Isnaini, chairman of the Muslimat Branch of NU, Magetan Regency, a political leadership area, in the sense of managing the government bureaucracy, women have the same rights. This same right is not said to be an unfounded argument, but rather a factual logic which has been believed to be a marker for the success of female figures in leading the government. Isnaini said:

" I have often said that in the area of government politics, there is a portion for women, there is a balance of opportunity ... in candidacy. The case of who will win is fully the domain of voters ... our obligation is participation ... the law also guarantees ... " (Isnaini, 2019).

In the above opinion, it is implied that the NU community and especially the Muslimat NU have an idea that the issue of gender imbalance in filling political positions or positions does not exist. Gender politics in the election of leaders in East Java has been addressed egalitarian, so that voters do not question whether the candidates for regional head are women or men. The same thing was expressed by the Secretary of the PC NU Magetan, Sudarto, who saw that the people of East Java, especially Magetan, would not give a counter-productive reaction in the discourse of women's leadership. According to him, on various occasions, women are indeed given space in the democratic party to elect leaders. The logic of society is no longer women versus men, but rather personal qualities which voters will perceive later. As he puts it below:

" .... I think for Magetan yes ... of course what I mean is that NU residents will not blamed whether the leadership of the government came from men or women ... it's just a personal election ... " (Sudarto, 2019). With thus the news or information that comes about the leader

women will of course be considered good. The informant took the media as an example preaching Khofifah running as a candidate for governor is not something that needs to be addressed emotional. Because basically there are disagreements about women on the political stage was completed before. It is clear from the informants' point of view that leaders can come from either gender male or female, because both have equal rights to participate in political recruitment. The Magetan people, according to Sudarto, were especially the Nahdliyin There is already one point of view in seeing the origin of the gender of a prospective leader. There is already gender awareness in this political recruitment, when it comes to determining figures a leader who will manage the government in his region.

Gender awareness has also automatically been embedded in the minds of members and NU Muslimat administrators, to the branches. According to Umi, the head of Muslimat NU Plaosan branches, both men and women are the source or origin of the same leader has the right to appear on the surface. According to him, the competition is not about gender, but based on objective abilities in managing government. That matter as he said:

"For us at Muslimat NU, of course we are very supportive of you, only support to the mother's not a matter of a mother is a woman ... is saju jenis sex with us .... Now ya can objectively see if we could say that Khofifah's mother is capable ... not that, miss ... " (Umi, 2019).

According to informants, the NU Muslimat members have generally accepted gender equality in terms of position and on the other hand they also support its existence leadership of women that they can see for themselves that the results of an organization led by a female figure is no less successful than an organization that is led by men. The general chairman of Muslimat NU who bears Khofifah is proof strength, and the plus points of women as leaders that they tend to get more bonding attention to fellow humans than a leader figure man who tend to be more indifferent to their members.

In line with the above, the head of the Muslimat NU, Takeran sub-district said that information about women leaders is very reasonable information in theera present. The Muslimat NU members have 
strongly agreed with the women's leadership, because it has been proven in leading women's organizations. Further informants say that:

$"$.... we in the branch have no problem at all, instead, we are grateful ... so the question is not necessary, he he he he ... yes, that means it's not in question for East Java, right? (Rusmiyati, 2019).

In strengthening her argument, Rusmiyati gave an example of Khofifah's success in leading an organization the size of Muslimat NU. Rusmiyati says that deep leadership he has carried out leadership roles properly seen from the results of several indicators that produced positive results on his performance. If a conclusion is drawn about the acceptance by members and staff to the figure female leaders, also generated positive responses in which they were very open and accept the existence of a leader figure among women. Information about women's leadership in the traditions of East Java society it turns out to also be a discourse within the community outside of organizations outside Nahdlatul Ulama and their wings, a kind of Muslimat NU. East Java Governor Election June 2018 left an important mark in the Indonesian democratic process, namely a society that is politically mature.

Golkar Party Wasekjen said ten female leaders out of 38 districts / cities plus one province are in East Java. This is the composition (regional head women) the most in Indonesia. It means, women's political awareness in East Java very high (Kumparan.com). Thinking about the political reality in East Java, where women also get the same opportunity as said by communication experts Airlangga University politics, Suko Widodo. According to him, the matter of the leader must be a man or may the woman have finished 15 years ago in East Java. Society and its kiya already open to gender issues. Because there is an awareness that women great exists. The graphic data below provides an illustration of this.

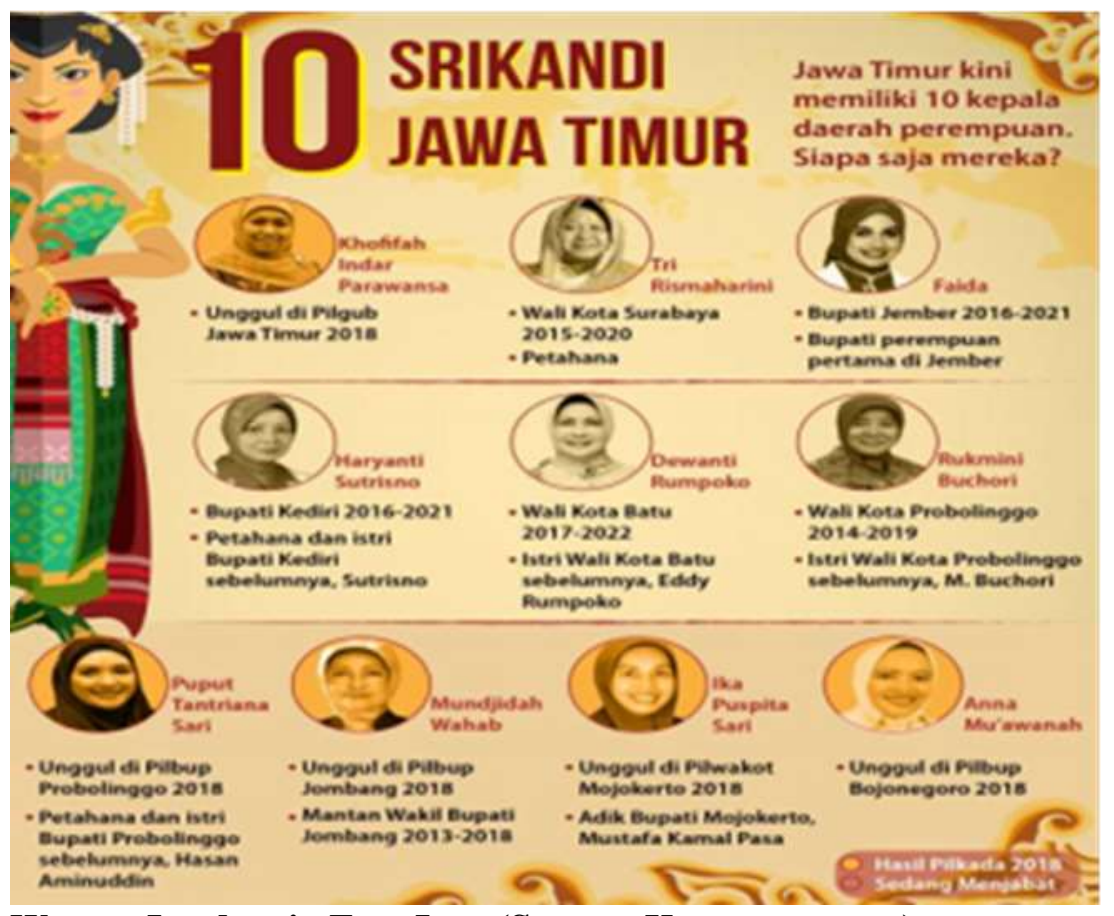

\section{Women Leaders in East Java (Source: Kumparan.com)}

From the statistical reality above, it is actually related to opinion at the root level grass, especially the Nahdliyin, the tendency is that the case of women has already been over. An informant from the Takeran area, as the region with the smallest number of Muslimatmembers NU, also said something that was not different. According to him, it's not his time to see any more women only as housewives, without a leadership role in government. He said: 
“... in my opinion sis, even though I am an ordinary member to see that woman too capable in government ... so information on the nomination of women leaders for those yeah true ... that's good .... "(Hapsari, 2019)

What the informant said was actually a reflection of the Javanese people East, in the context of this research, is the community or Nahdliyin residents, more specifically again the Nahdliyin residents of Magetan Regency see positively if women take the lead government. The informant also connected with information about the figure of Khofifah is seen as successful as a leader. Leadership is very influential on organizational achievements. Muslimat NU is an advanced and successful women's organization on a national scale. In the expert's view, the activities and performance of members of the deep follower organization is largely influenced by the presence of a leader. The meaning of leader is a person a person who has skills or advantages in an area so that he is able to influence others to jointly carry out certain activities for the sake of achievement of one or several goals (Kartono Kartini, 1999).

\section{A.3 Informant Assessment About Khofifah-Emil's Candidacy as Governor of Java East based on local culture}

Pencalolan Khofifah - Emil Dardak as a running mate for the Governor-Deputy Governor of Java From the cultural side of Java, East has received a positive response and is still relevant to local culture. The phenomenon of Khofifah's electability gave rise to the true passion of the Magetan people, especially the Muslimat NU members in seeing the Javanese culture that places women as a wingking konco or a figure who only deserves to be in the kitchen, as a wife. According to Chairman of Muslimat NU Magetan, Isnaini, Javanese cultural values where women only act as Konco Wingking, interpreted as more wise and broader. The informant said:

" ... I think Javanese culture should be interpreted this way ... women as konco Wingking is his function in the chaos of kitchen matters ... domestic affairs ... and when it can be resolved, it can be resolved so it is permissible for him to be in a public space ... that's right Ms. Fitri ... "(Isnaini, 2019)

The thinking above reflects that it is permissible for women to work more widely in the public space, while still paying attention to its supernatural domestic roles attached to it. The informants see if the domestic space has finished the debate, if only question the women in it. Now men have started touching or entering the domestic space of women by changing the role of women, there are total and partial ones. This is the consequences of a situation where, the necessities of life that cannot be postponed and the lack of quality human resources itself. Isnaini sees this as a form of " compromise " with life necessities.

$"$... the necessities of life are obliged to be fulfilled ... the clothing and food boards .... para a husband who has no advantage ... then gives up his wife to become a migrant worker, he is in Indonesia takes care of children ... that's proof that the world is now where it can be walking ... " (Monday, 2019).

Lack of employment opportunities for men in Indonesia, according to informants become one of the triggers for how women are involved in the public sector. Role culture about women is actually very biased for women. Women seem to be imprisoned by the confines of tradition and cannot free themselves at the same time from the domestic burden when working in the productive domain. Women who work outside the home cannot focus on their dreams, but are trapped in two worlds at once, in the productive and domestic world, or what is known as a double burden burden).

Sapiro in Ardaneshwari (2014: 25) says, "The classic tendency to opposing the position of women and the world of work based on unwarranted concerns that by working outside the home, family and also the woman herself, will be disturbed". Candaraningrum (2014: 14) emphasizes that women return home After his formal work, he will work on the second shift job. He confirms this is a very tragic 
fate for women, not because resistance or dislike of domestic work, but women it takes time to rest, reflect and weave itself.

That Khofifah is a female figure, tradition in NU does not matter that is because the duties of women leaders are in the governmental area if it is women who lead is not a problem at all. So that information is always on be positively addressed in the sense that it does not cause structural dilemma problems. This reality is seen as mere political discourse.

The culture of the Magetan community which is included in the Javanese kulonan too influence NU Muslims in providing support to Khofifah in nomination as Governor of East Java. As stated by Mrs. Isnaini, the chairman Muslimat NU Magetan.

".. The majority of the people of Magetan are abangan and their thinking is more modern, which in deciding something is based on many factors unlike the site area What horses are obedient to the kyai ... this is one of the factors in his selection Mrs. Khofifah ... "

The same view was given by an informant from the Muslimat branch of NU who with the fewest members, namely the sub-district of Takeran. Head of the branch Muslimat NU Takeran said that the information on Khofifah Indar Parawansa's candidacy is a form of interpretation of the abangan people who have an open mindset about a leader. women to be number 1 in government is a sure thing in this era of democracy.

".. the information on Khofofah's nomination - Emil has been coming to us for a long time, right? Ms. .... yes, that's good if in my opinion and the Muslimat NU residents in Takeran this ... maybe it's because you are quite famous ... after all, the problem of running is already in the third place time for the Governor of East Java.... although women are not an obstacle bu Khofifah advanced to be governor, the state law also does not prohibit, at Javanese Abangan culture also does not prohibit women from becoming leaders the opportunity ... we welcome of course the candidacy information " (Rusmiyati, 2019).

With the description of the internal organs of Muslimat NU above, information on Khofifah's candidacy greeted by the Muslimat NU Takeran residents well. And apparently the Muslimat NU members Takeran saw this because the candidate's popularity was already strong. According to Rusmiyati, however, Khofifah is a recognized national figure national, namely as a former minister of social affairs. Apart from that in the internal scope of Nahdlatul Ulamapun, Khofifah is really not a foreigner and is recognized as a person leadership. Khofifah is the General Chair of the Muslimat NU, which oversees it NU Muslimat organizational structure throughout Indonesia. The nomination information will inevitably be swayed by capacity proven and tested leadership. Such evidence and testing is particular within NU's internal territory, namely through the Muslimat organization wing of NU.

From NU circles, especially NU Muslims, information about this candidacy is of course has its own value. The sequencer of the Muslimat NU branch of the Plaosan branch for example, see the information as a blessing. Blessing in a sense, as a twig has the highest number of members in all branches in Magetan Regency, it will indirectly confirm the existence of the Muslimat organization NU in Magetan district. This was as said by the Head of the Muslimat Branch of NU Plaosan sub-district as follows:

" The information is a blessing for us, however we are proud of our Chairman enter a wider public domain .... namely leading the government in East Java. Therefore, yes, we clearly support ... in the past, you had already nominated me right ... but not sustenance ... this may be an opportunity given by Allah SWT .... I see Ms. " (Umi, 2019).

When viewed from the results of the interview, the informant's assessment of the information Khofifah's election as Governor of East Java is positive information. The informant added that in public 
or government leadership, women are have the same rights as men. Hence when Khofifah voted representation of women has the opportunity to run for office, so there are things that should be considered political appreciation by giving real support to elections. Apart from that, actually, according to Umi, it is not a matter of women or men, the information is more to the ability concerned in managing work on government level. So that it is actually separated from the issue of gender. There is equality gender in this context, so that the information according to the informants also informs gender justice. Information has positive value and makes women proud, especially in internal NU Muslimat residents in Magetan.

A somewhat different opinion was expressed by one Muslimat NU member who saw the nomination information as something that reported a demotion for a woman leader like Khofifah who is running as a partner Governor- Deputy governor of East Java. According to an informant, a member of the Muslimat NU branch That saying, it is actually a bad sign, the information is of poor value, as is he said as he said that:

" If I personally rate the information as the fact that there is a decrease in jabatan... time of the minister of national nature or scope of work, a certain degree of regions ... but if that's his decision, yes we Muslimat NU citizens can only support that ... maybe also for East Java which is better ... that's what it is, sis " (Lia, 2019).

In an organization, regardless of the organization, differences of opinion are certain therefore it also applies in viewing or judging nomination information Khofifah as Governor. One of the Muslimat NU members who became an informant was precisely this questioned the motive for the candidacy which he perceived as demotion. According jabatan Khofifah as minister of social affairs nationally far more beneficial than being Governor at the local level. This is the point of view of a Muslimat NU member Plaosan. Assessment of information on the candidacy of the Khofifah - Emil Dardak pair as a partner The success team responded by the East Java Governor as an easy message to convey. The informant said that as a successful team the nomination information was predicted to be easy accepted by constituent communities in the Magetan region. As said Wati, one the following members of the success team from Magetan district:

$"$... I ordered or the information regarding the candidacy of Mrs. Khofifah is information which is easy to convey to the wider community ... in this case of course is this NU Muslimat member in Magetan. Mother already has high social capital this context, then we as the success team see or assess the information nomination as an easy and good thing to convey to the public, especially the Muslimat NU residents in Magetan ... that is, if I miss "(Wati, 2019).

What the success team said above is a form of based explanation in his empirical experience doing political work as a team to nominate someone in regional elections. In his notes, provide that information, so that the public is expected giving an assessment, in the field what happened was that the nomination information had already been completed. This means that it will definitely be assessed as positive information. The informant added that in this context, there are things that are material for residents the community and Muslimat NU members to assess information about the thawing. material sociologically, it is often said to be social capital. Khofifah is clear has a large social capital, such as the former social minister, chairman of NU's four times in succession - succession and once ran for governor of East Java juga period - previous period. This social capital itself is a material for assessment by people.

\section{B. Dimensions of Assessment Weight}

With regard to informant trust, it is a function of credibility. If someone considers the information to be true, then that information has great weight higher, and vice versa. 


\section{B.1 Informant's assessment of the Track Record of the Khofifah-Emil pair.}

Credibility is an important thing in conveying information in the communication process. Assessment an informant regarding the reliability of the Khofifah - Emil pair was revealed from the results of the interview researcher with Isnaini, Chairman of the Muslimat NU Magetan district. According to informants, the credibility of the couple is not in doubt. Both are para officials who are experienced in managing governance in this country. Khofifah justru resigned as minister of Social Affairs, not backdated for reasons certain that are counter performance.

"... the credibility of my partner we are not in doubt... if we will see... how they lead their respective organizations. That fact can be verified through among others, the news in the mass media which assesses positivity ... or the bond structure the organizer where Khofifah is part of .... also provides information about the credibility of the couple ... "(Isnaini, 2019)

Informants said that there are at least two ways how to record traces the candidate for the pair of governors by looking at how the mass media reported credible, and also through the organizational structure in which the person concerned belongs. News from credible national mass media such as Kompas or Jawa Pos, regarding The achievements of previous post-office positions are a source of information that can be used for convince and add material for making decisions. Through the organizational structure, according to the informant will provide information regarding the credibility of the leader candidate to be elected. Khofifah who is in the top structure of organizations such as the Muslimat NU of course provide information regarding the credibility of the respective prospective leaders.

Secretary of PC NU Magetan, Sudarto also said that his party saw the candidate for governor as a credible figure on the grounds of his track record leadership that is clear. Khofifah has a character in this context as a capable leader in the government bureaucracy. The informant said if in the internal circles of the Nahdlatul Ulama he is a figure has a position and meaning. She said:

" ... for Mrs. Khofifah, I think the credibility issue is over Ms. ... the problem is that she has a position and meaning in a good organization government bureaucracy and internal NU ... buy in its capacity and position right I think ... " (Sudarto, 2019).

The informant openly admits that what Khofifah was doing so far this is a clear reflection of his credibility. Visible activity is a measure - a real measure as well as the impact or effect of the action leaders in society. Thus the good lunge itself has been is information that reflects the credibility of the prospective leader. If we relate to theoretical references, credibility according to Jalaluddin Rakhmat (2005) in a book entitled "Psychology of Communication", credibility is a set of perceptions of communicates or audiences regarding the characteristics of the communicator. In this case credibility contains two things: first credibility is the perception of the audience so deep This context, credibility is not internal or inherent in the communicator, both credibility with regard to the traits of the communicator.

According to the head of the Muslimat branch of NU Plaosan, the credibility of the caliph is not necessary questionable again, because it has been proven empirically. Evidence that can be given is when Khofifah held various positions in the bureaucracy and in the environment the Nahdlatul Ulama organization. Various positions that demand credibility have been carried Khofifah.

“... Khofifah's mother no longer needs to be carried - weigh to what extent its credibility, the discussion about that is over ... so it's in my political communication to the Muslimat NU members here 
only to strengthen it ... add just faith, after all, he is our leader at Muslimat NU, we know exactly ... " (Umi, 2019).

With the above expression it is clear how informants are no longer take issue with things - things they think have been fulfilled or have been achieved. Thus the Muslim community of NU for Plaosan sub-district can be said already very confident in the figure of their future leader in East Java. Informant said that we already believe in the credibility of the candidate because of his expertise in managing the government or organization. In the communication perspective, the candidate is a credible figure because he presents three source credibility component, namely the expertise (expertise) which is an impression formed the receiver about the ability of the source of persuasion communication related to the topic which is discussed, can be trusted (trustworthiness) which is the impression the recipient about sources of communication related to character such as honesty, sincerity, attitude fair, be polite, behave ethically or otherwise as well as the factor of attractiveness of the communicator or (attractiveness) which includes physical and non-physical attractiveness of the communicator.

Presentation of one's self is important, especially regarding communication a figure before the public. On many occasions, public communication figures or some government officials are said to be very bad, so sometimes in reality public communication there are officials who are said to have poor public communication. In the context of this research, the intended communication actor is a candidate The Governor of East Java, who previously served as a level bureaucrat national. So Khofifah's presentation in the discourse of political communication in the public sphere in general, it can be assumed that they are possessed. After all Khofifah is an ex the social minister who of course will be assumed to be in control of public communication. NAmun so, because this empirical research it is necessary to collect data as much as possible how exactly the informant's assessment of how Khofifah presented himself in the discourse of communication in front of the constituents, in this case are circles Muslimat NU Magetan.

According to the Chairman of Muslimat NU Magetan, Khofoifah's self-presentation ability really good, the presentation was not only in terms of speaking in front of crowds yet juga relates to how in bringing gestures, eye gaze and other as well. From there, according to Isnaini, Khofifah displays maternal nature in terms of This is considered to show a way of leading that is more touching to the community emotive. Isnaini says:

" In the previous regional elections, only a handful of candidates for regional leaders women who succeeded in leading the voice. However, in the 2015 Pilkada, it happened a significant increase in the number of votes for regional leaders girls.... this happens because voters have high expectations. Voters Jugaexpect a leader motherly nature, "(Isnaini, 2019)

Of course, according to the informant, people who have these expectations have flocked to make choices on female regional leaders. That that is, the Pilkada this time also reflects a change in voter perceptions. Trust voters to women increased. Nowadays people are thirsty for leaders who have a conscience. With the presence of female regional leaders, voters hope society's expectations will a figure of conscience can be answered. The presentation of himself in Khofifah's candidacy was also not only assessed how candidates communicate politically with their audience, but also from aspects others which according to the informants represent their existence. According to the Chairman of the NU Muslimat branch Plaosan, Umi, the candidate for governor of East Java presented himself in aconcept low profile. He gave an example, for example in the matter of the governor candidate's dress simple, even when the e campaign conducted a public dialogue with Muslimat NU citizens and constituents in general. According to Umi:

"... I saw that self-presentation was not limited to being able to speak, about speeches here and there of course .... one of the presentations of Mrs. Khofifah is the clothes she is wearing presents himself with a low profile... plain white shirt with black pants... Ms.... that aspect is interesting... .oh yes then 
about the hijab... it's that simple... love pin on the chin .... the necklace is already ... simple ... "(Umi, 2019). From the informant's information, it can be said that the informant's assessment of Khofifah's selfpresentation leads to positive things because, for example, it is represented by costumes or Khofifah's dress which is considered simple. According to the informant, he was previously had time to wear a white shirt which cost around Rp 400 thousand. But it is precisely felt uncomfortable until he took it off. That's why he prefers to wear clothes the ingredients are delicious and cheap. With a choice of comfortable clothes, according to him, it is more flexible for moving. And do not limit himself to greet the wider community. Besides the suit The style of clothing that is also the hallmark of Khofifah is the veil. Even now already a hijab model trend the manifold.

NU's Chairman of the PP never replace her hijab style and stick with a hijab model that is pinned under the chin, and draped to the side with a silver circular brooch. This is a characteristic that cannot be separated from Khofifah. According to him, the hijab style is simple so as not to waste time and most importantly not weird.

\section{B.2 The informant's assessment of the pair's political abilities.}

Political ability has influence in decision making and is capable boost the positive value of prospective leaders. This can be explained in recruitment leaders, one of which is filled with the disclosure of the vision and mission by the participants the political contestation. Likewise with the democratic party that was held at this East Java province. In this regard, candidates as stated in the mandatory rules for describes its vision and mission. According to the informants, vision and mission are one measure which is used to judge a candidate, before a decision to choose who that candidate is the desired constituents are determined. According to the informant, Khofifah's vision and mission is quite good, so that when it is described it will also be proud.

" ... I think the vision and mission is good ... it means that it has a mature and good concept ... right ... that's a reflection of what he will do during his leadership someday " (Umi, 2019).

According to the informant, if the vision is dissected, there are two important elements, namely the ideals of the realization of justice, prosperity, excellence and noble character the people of East Java. In addition, namely the realization of a large collaboration between government and society in achieving their goals by prioritizing enthusiasm mutual cooperation as the noble value of the Indonesian nation that will bring the people to be able overcoming challenges and limitations. In our vision there is fairness, prosperity, so in it there is justice in access like which is conveyed in the vision and mission.

Access to justice in it is connectivity or connectedness, especially for southern or coastal areas, island areas. While for missions that will be carried out over the next five years, he continued, there are seven missions. Among others balance of economic development, both between groups, between sectors and between territory. Including the creation of socially just welfare with attention vulnerable community groups and the fulfillment of the basic needs of the people of East Java which includes health insurance, education security and building food sovereignty, which includes easy access to employment opportunities and connectivity territory.In addition, there will be clean, open and participatory governance. Then, strengthen civic democracy to provide respectful social space the principle of diversity, and environmentally sound development to guarantee harmony of ecological space, social space, economic space and cultural space. The importance of the vision and mission of the candidate for Governor of East Java, was also said by the Chairman of the Branch Muslimat NU Plaosan who sees that the Vision and Mission is the candidate's identity applied to the region. According to him, there is no nomination of a leader or regional heads who just came without conceptual capital.

As it is known that in the vision and mission that was launched by Khofifah, the concept was carried is Nawa Bhakti Satya. Surely this is a lot of things to be communicated and synchronized with the 
draft on the technocratic framework that the provincial government has. These nine devotions or dedications are directed towards the realization of East Java which is noble in the eyes world through contextual multi-sectoral and multi-dimensional competitiveness building global. Including noble in the eyes of the people with the presence of the government in making it happen welfare for society fairly and equally. The chairman of Muslimat NU Magetan, Isnaini, said that the vision and mission are in nawa Bhakti satya is basically a guide and basis for the service of the elected governor in front of it later. In realizing this service, the governor must be consistent against the administrative order that has been described, namely optimizing the role provincial government, both as the central and regional bridges, executing authority affairs province, as well as encouraging synergy in the implementation of district and municipal authority affairs. Meanwhile, in the application of Nawa Bhakti Satya, his party has formulated it into Bhakti Jatim Sejahtera, Bhakti East Java Healthy and Smart, Bhakti East Java Work, Bhakti East Java Access, Bhakti Jatim Agro, Bhakti Jatim Blessing, Bhakti Jatim Berdaya, Bhakti Jatim Amanah, and Bhakti Jatim Harmoni. Bhakti Jatim Sejahtera is a dedication realizing the people of East Java who are lifted from the problem of poverty for the sake of achieve justice and social welfare. One of the excellent programs is Family Hope Program (PKH) Plus. Where the program is a program central government that has the potential to have an impact wider and more significant.

As stated in KPU Regulation No. 68 of 2009 concerning Technical Guidelines for Nominating Regional Head and Deputy Head General Elections Area. There, it is stated that one must be attached to the nomination letter will candidate pair is a written written vision, mission and program of the candidate pair. Furthermore, regarding the vision and mission, it does not stop there, according to article 11, article 12 and article 15 of KPU Regulation No. 69 of 2009 concerning Campaign Technical Guidelines General Election for Regional Heads and Deputy Regional Heads, it is further regulated that the vision, the mission and program of the pair of candidates in implementing the campaign must be written, must be submitted to the voting community and will become an official regional document. More than that, if a pair of candidates is elected to be the Regional Head and Deputy Head Regions, so that on this basis, it has become an obligation for the KPUD as ELECTION organizers to facilitate the dissemination of campaign materials includes the vision, mission and programs of the candidate pair to the community in order political education.

By paying attention to the above regulations, the vision and mission should be the candidate pair program cannot be ruled out anymore, it should get attention from all levels of society, because apart from this it concerns sustainability regional development, will also have a direct impact on the welfare of the community. And the delivery of everything supporting both future programs, personal information leaders should be conveyed proportionally and continuously to constituency understand and understand and finally choose. Can be done with a variety of media both social media and through regular meetings.

A Muslimat NU informant in this study said it was important vision and mission. According to him, the candidate pair for governor Khofifah and Emil will run vision and mission after taking office later. In his view Khofifah is a person simple and trustworthy, as he put it:

"... I really believe that Mrs. Khofifah will carry out her vision and mission with you Emil and the East Java bureaucracy.... Yes, there is a kind of moral argument... chosen democratically, because the people desire this, this is what I think is embedded ... " (Wati, 2019).

From the informant's explanation, it appears that his opinion is a good leader according to the expectations of the people and the election process carried out in a democratic manner according to legal regulation in the form of general elections is the dream of all Indonesians of course. So that the people don't even know the vision and mission of the candidates Nasiolan leaders who will compete in the democratic party in the form of general elections regional / pilkada heads (legal determination of national leadership, according to law) which is handled by the general election commission (KPU) at all levels as well as at supervised by the election supervisory committee (Panwaslu) at all levels as well. 
Of all the candidates for regional leaders who participated in the post-conflict local election stages these are the best sons of the nation and are the best sons of the nation very sincere and sincere will serve for this nation and country. The informant's assessment of the communication skills of the Khofifah-Emil pair is a dimension in this study. Ability communication for a leader is indeed one of the important keys when interact with the public. The informant has several assessments of his own the candidate pair. According to the informant, the head of Muslimat NU Magetan, the abilities of Khofifah and Emil in communicating there is no need to doubt. Khofifah as a Javanese is certainly very master the Javanese language, so that when the campaign was carried out there was no public communication trouble. This is certainly beneficial as a regional leader candidate. More continued Isnaini said that:

"... They are good at communicating ... they are already good at working with public officials... me argued generally the communication was understood ... yes it is possible sometimes sometimes it is also for old people, right there is also a word meaning that is not understood... yes parents who have limited knowledge... .maybe Muslim members who don't have or don't understand the terms certain... "(Isnaini, 2019)

At the leadership level, the informant admitted that it was indeed the ability of the Khofifah pair communicate no need to doubt, so it can be said what is communicated by Khofifah can be understood by members of the Muslimat Nu, especially Magetan. The exception is indeed for members who do not know the terms used by Khofifah when giving speeches. The chairman of the Subdistrict NU Muslimat Subdistrict also said the same expression Plaosan who argues that the overall communication ability of Khofifah no doubt so that it is very strong to be a suitable figure lead an area or territory. According to the informants, one element that must be sufficient Prominence is the ability to communicate, so a measure of that is visible in Judging a leader is seeing how he or she communicates work program. The informant further stated that:

" ... in my opinion, sis .... his communication skills are very good ... us everyone understands, right communication is delivering program programs... what's more right, Khofifah's mother is from East Java... so sometimes she inserts her speech Javanese language .... just sometimes unconsciously use the word for some people considered foreign .... priority words for example ... there are people who don't know, but we do We have a wa group, if for example someone is confused by a Muslimat, we are the branch leader who explains .... " (Umi, 2019).

According to the informant above, actually good communication is relatively good by the candidate for governor of East Java. Strengthening program delivery of course through communication which in this case is assisted by well-controlled means of communication by the majority of the audience or communicants. In terms of Khofifah's political communication when do a campaign, do not be surprised if Javanese is inserted as people's mother tongue - people in East Java. Indonesian has actually become the most powerful language by the Indonesian people, although some do not understand the terminology certain terminology. Words that are considered foreign because of the different breadth of knowledge this is what is often considered a foreign word and needs an explanation of its meaning.

Assessment of Khofifah's communication is basically the delivery of messages from the sender to the public. In order to complete Khofifah's verbal message, there was a message others that can be delivered in various forms ranging from posters, banners, billboards, speeches, advertisements, whatshapp groups, to flyers. Whatever the form, messages always using symbols, both verbal and nonverbal that are expected to provoke audience response. Campaign objectives can only be achieved when the audience understands the message shown to them.

\section{B.3 Informant's assessment of communication style}

Leader's communication style is able to influence voter decisions. In This dimension will be seen to what extent a leader will trust his position with one of them is running programs that have been 
launched during the campaign period. This is something that is generally held by the community as important in assessing the degree of trust of a leader.

According to the informant, the pair Khofifah and Emil Dardak are believed to be run work programs as promised during campaign. Thus there is a kind of confidence that grows in the constituents when faced with a political choice, namely Khofifah-Emil. Isnaini as an informant major in this study said that:

" ... I believe that the couple will lead East Java, so that ... when asked will they run the program that was promised, me say firmly ... they will carry out that promise as well - the good thing ... experience has proven how much Khofifah's mother ever was became a minister, became chairman of the Muslimat NU. And we also know that how Emil became the regent of Trenggalek, of course that was it presets .... from where measure it if not from the implementation of the promised program all of it ... " (Isnaini, 2019)

From the information above it is clear that actually for the Muslimat elite NU in Magetan, there is absolutely no concern about whether the leader who elected later is a trusted leader in the sense that he will run the program his program after taking office. The basis of belief is of course the experience that is owned by the pair as bureaucrats at the national and local levels.

"Yes, if that is directly equivalent to this process is what Emil did, because it was based on programs and masses. Mrs. Khofifah is indeed a bureaucrat, but not mass-based and programmatically based right away... Mrs. Khofifah translated what the president wanted, style Communication is not only during the campaign, sis, usually we are the committee and Muslim friends often do recitation together as well as discuss it support to Mrs. Khofifah, besides that, there is a WA grub who always provides information about future programs such as being elected governor ... " (Isnaini, 2019).

In fact, the belief in the leadership's mandate remains, in this case the pair Khofifah and Emil Dardak have also been expressed by internal circles. Muslimat NU, especially at the branch level under the leadership of the Muslimat branch of NU This magetan. Muslimat NU Ranting Takeran sub-district, for example, sees that there are two the basis of the belief that the NU Muslims in Takeran to KhofifahEmil, namely experience and diversity. Experience according to Umi, is the most relevant indicator in this context. because the experience done is the work experience done with good. Experience of performing tasks with real and perceived effort the benefits directly by the community. Furthermore, Umi said that:

$"$... I think that the declaration of a vision and mission means in general the person concerned is an experienced person so it can be said to be deep This also follows the nomination rules, sis, meaning that it meets the rules Pilkada... that's not it, Khofifah-Emil if they campaign occasionally Ms. use Javanese so we can understand, besides that, information about His program was also conveyed in the WA group and the recitation meeting became clear we have a picture of his future leadership ... " (Umi, 2019). What was revealed by the head of the Muslimat NU branch in Takeran sub-district shows that the communication style of the Khofifah-Emil campaign is not only oratory. But Jugasocial media have penetrated either through personal accounts and groups formed to succeed in winning the two candidates. Even in The NU Muslimat organization has also conducted socialization from the WA group or routine recitation during which the program from the No. 1 candidate in East Java was inserted.

\section{B.3 Informant's assessment of emerging gaps}

Inequality appears between the valence and the weight of respondents' assessment of interpret women leaders in politics and strategic positions. The inconsistency arises because of the opposition 
between the two. Such that revealed by a member of the Muslimat NU Lembeyan, who still thinks if the leader must be male.

"... The leader must be a man, that's already been written in the Al Quran Surat An Nisa, but yes Mrs. Khofifah is different, yes, she has competence more so that we NU Muslims, the majority of whom are women, support him go forward to be the Governor of East Java, he is also the leader of the National Muslimat NU, .. " (Anik, 2019).

Another thing was expressed by Rusmiyati, the NU Muslimat committee member, Takeran branch, he also revealed the gaps that exist in the Nahdilin, which the majority follow anything which was conveyed by the Kyai especially in the Tapak Kuda area.

“... What I hear is Ms. NU, especially the group of men or those we know in the term GP Anshor supports Saifullah Yusuf, while the mothers support bu Khofifah, maybe if in the NU area the hooves will just obey whatever Kyai conveyed it, but in Magetan, the Javanese Kulonan area is the majority of the people Abangan, Kyai can still be listened to, but the choice is yours, .. " (Rusmiyati, 2019)

When making choices based on valence, both religious and gender values no one supports women as leaders. But with the weight of the assessment in terms of credibility, political ability, and Khofifah's communication style as a means boost it to be worthy as a leader. From the gaps that appeared between both, Muslimat NU negotiated in determining his choice.

\section{Negotiation of Information}

Regarding the alignment between the valence and the weight of the NU Muslimat's assessment in determining Khofifah's choice as female leader. Both determined by yourself and influence of a group or organization.

\section{C.1 Private Negotiation}

In this dimension of personal negotiation it is based on the knowledge that is owned informants regarding the candidates who ran in the political competition. This is of course its nature

very subjective considering the point of view used is an individual point of view or the informant's personal. However, the power of opinion leaders in a community or organizational structure, becomes something that really determines the direction the preference or political support of a person / member of the community.

Psychological point of view, women are generally assumed to be weak, so that degree of emotional stability is not favorable to lead, especially to lead at the government level. But empirical reality provides evidence that leadership the public for women has also happened quite a lot. One of the proofs as is disclosed in the above section review. Nevertheless this research will ask the views or perspectives of the informants related to this research. According to the Chairman Muslimat NU's Magetan branch, Isnaini, linked women's leadership to Their psychological condition is considered weak to be less attractive. According to him, if it is indeed weak, how can there be a state leader? a woman.

".. I think yes, the condition of women is said to be psychologically weak, so considered to affect his work ... but every day is not the day - the day those who have to make decisions ... after all, there must be other officials who help make decisions ... right ... " (Isnaini, 2019)

What the informants said is actually a reflection if it is true women claim that psychological characteristics are not a thing become an obstacle to women's careers in the government sector. In government, actually the leader is not single in practice. There are officials who do into a structure 
bureaucracy to run the wheels of government of a region. According to informants, when a leader who has to make political decisions for the community will certainly have a dialogue with various parties.

"... actually it can be seen that the government is not a governor or the regent himself, there are other officials, there are members of the council, right ... what are the figures the community ... about the regional regulation, for example, of course as a political decision one must get it approval from the legislature first, in the sense of DPRD ... yes sis " (Isnaini, 2019).

According to informants, fear of mentality or the weak side of women psychologically something is actually unnecessary. Female leader when designing decisions is certainly not in as bad a condition as one might think. The thought construction was the informant's observation as a former official in the environment Magetan district education office who interacts with other leaders. The Secretary of the Magetan Branch of NU saw that psychological problems were a problem which was not a casual obstacle that completely paralyzed his path government. Psychological problems are indeed considered a weakness of women, however Of course there is another side that is the strength of women themselves in leading a organization. Sudarto said that:

"... I think yes, this is my personal opinion to see or consider leadership these days it's too naive to use only psychological parameters ... huh indeed it is important ... but isnt there any discrepancy on the other side ... this should be seen fairly ... "(Sudarto, 2019).

The informants see how leadership cannot be seen from one side only showing a weak side. Behind the weaknesses, of course, there are advantages that are more needed rather than just sticking to a point that is considered fatal as weakness. In politics is indeed the raw material for bringing down deep opponents in fact for East Java it is not visible. The informant gave an example of how the past was where women or girls were get the crown for wielding great bureaucratic control. Queen Balqis is a figure that was reported in history, how women hold the throne properly. "I think ... we are now individuals who are already at a democratic level in seeing women in governance ... Gloria Arroyo, Teacher, Putri Sima ... come on who again sis... yes Putri Sima ... how is the assertiveness ...right ..." (Sudarto, 2019). Obviously according to the informant, the path of choosing a leader may be too naive if you look psychology as the sole reference and considered fatal in political recruitment. In Indonesia today, especially East Java, issues that rely on psychological problems as a contributor weak in determining company leaders.

In psychological discourse, there is a kind of reality that scientists express that psychologically women are easily influenced and easily persuaded to change his belief. According to Maccoby \& Jacklin (1974), in a situation there is no contact even with the persuader, women are more receptive than men based on consideration of the consequences it assumes. This shows there is differences in conformity between women and men, but the differences are very much thin, even the difference in conformity of these women is considered positive because consider the consequences that will arise at a later date that are generally not thought of detail by men (Becker, 1986; Eagly, 1978). Regarding psychological obstacles, Muslimat NU leaders in Takeran District saw that in fact the psychological affair of women can be a giving turning point a shock to his leadership process. Rusmiyati emphasized that women could be more firm and stick to the rules that have been agreed upon than men. That deep life has the view that women leaders are more difficult to compromise, to be invited to play an inappropriate role.

" ... I actually saw some women leaders succeed ... how would it be successful if highlighted is a psychological weakness, Mrs. Risma, the Mayor Surabaya ... respected him ... we actually have to be aware of how the body, as women or men are only as " containers " for human characteristics itself .... "(Rusmiyati, 2019). 
When viewed from the leadership of women according to the view of the informants above, it appears she saw more about how women could be strong and assertive in leading the government. Even as a woman or as a man - again really not the right parameter to be a measure of choosing a bureaucrat or government leader. This matter according to the informant, this reflects that weak psychological questions should not be asked really not in the right direction. Furthermore, when we relate it to a theoretical perspective, women are more psychologically expressive. Women are often imaged as expressive behavior but men behave instrumental is associated with relationships in the social environment. Women are more attached and capable do interpersonal relationships than men. Both instrumental and expansive behavior demands skills and is expected to exist in each individual. Therefore, being expressive doesn't mean just emotionally driven and incompetent, either way behave instrumental does not mean only driven by ratios and more competent. (Hyde \& Lynn, 1986).

When women act in ways that conform to role stereotypes gender, they will be considered positive, but when women are in that leadership showing masculine traits, such as assertiveness, courage, never giving up, is considered negative because it contradicts the stereotypical gender roles expected by society. Although according to Eagly \& Johnson (1990) found no difference in interpersonal orientation as well as task orientation between women and men, but women leaders generally more democratic and less directive than men. Bylsma \& Mayor (1994) only found, women tend to feel satisfied when their achievement is exceeded women fellow (in-group), although less profitable when compared to career status, position, and salary of men by profession. Status differences with men are frequent neglected by women.

Isnaini as the head of the Magetan branch of Muslimat NU said that knowledge personal about Khofifah for a long time because organizationally he is included subordinates of the Chairman of the Muslimat NU. Isnaini further said that:

" .... yes, if my personal knowledge about Mrs. Khofifah I think I know he is a simple person, honest and working hard... .. I can feel if he donated his time and life for organization..it is something expensive ...... then this is my perspective miss .... maybe people, especially outside Muslimat NU, are naturally have Different perspectives .. back again Ms. Fitri, Khofifah's credibility already tdak doubt, he was chairman of NU's, had been a minister, jEnjang education also qualified, lacking anything else, I think beliu very competent to be Governor ... " (Isnaini, 2019).

Everyone's personal knowledge with the same object will certainly be different perceptions and views. This is what then becomes one of the considerations in making one's political decisions. Thus, according to informants, its subjective nature is determined by the extent to which a person knows the candidate from knowledge side. Knowledge in this case is the knowledge that they get from various media and in various interactions.

According to Isnaini, knowledge about potential leaders can be identified from various means of information that we can access. That information can be with various vehicles, both mass media and communication within the organizational structure. Now the mass media and social media has spread very widely, so knowledge about candidacy regional leaders can also be obtained.

\section{C.2 Negotiation of Muslimat groups / organizations}

According to Swann's concept of negotiation, self-stability is a form of process self-formation and social reality. (Swann, 1983) The concept of female leaders in Muslimat NU will not be realized if there is no development of the quality of the inner leader this context Khofifah and the environment that supports it. Khofifah got the opportunity to run in the election for Governor of East Java together with Emil Dardak supported by the Democratic Party, Hanura, Golkar, PPP, Nasdem. Although Khofifah is a woman, she is able to show her existence and credibility as a leader. The number one person in East Java has levels qualified education and has held strategic positions in government, namely as Minister of 
Social Affairs. As well as serving as chairman of the Muslimat NU. This makes women's organizations in NU fully support their chairmen to advance became the Governor of East Java. Various supports are manifested in various kinds of activities, such as those Isnaini expressed,

“... Even though the khofifah is a woman, we are Muslim NU especially those in Magetan very supportive of him being the Governor, support is manifested in his In the grand campaign in Magetan, Mrs. Khofifah gave a big helping hand so that we are excited teach him, he also supports the existence of Warung Muslimat NU which incidentally the providers of the Muslimat members themselves sell food for the people and community, besides that we also often carry out routine recitation in between We inserted the Bu Khofifah program, and didn't forget that we also exchanged ideas frequently as well as sharing information about Ms. Khofifah's candidacy in the WA group. For example, there is one Muslimat who does not understand, the head of the branch and the committee who will explain, for example, miss, if someone is an older person who does not understand language or words delivered by Khofifah, later the management who helps explain,.. "(Isnaini, 2019). The same thing was also revealed by Umi, the chairman of the Plaosan NU Muslimat Branch,

".. Muslimat NU Magetan is compact, Ms. Fitri, yesterday there was one

The grand recitation that Mrs. Khofifah visited, we prepared the food, we make public kitchens, for the thousands of people who come, in my study always convey about the Khofifah program, according to the direction of the leadership, and Alhamdulillah, my subordinate Muslimat are also supportive, they are even happy really if the khofifah becomes the governor so later our mandate as women will be easy to hear, .."(Umi, 2019).

\section{Matrix of Research Findings}

\begin{tabular}{|l|l|l|}
\hline $\begin{array}{l}\text { A. Integration } \\
\text { Information }\end{array}$ & $\begin{array}{l}\text { A. 1. Information Integration Valency } \\
\text { related to religious values } \\
\begin{array}{l}\text { Muslimat NU supports because the presence of } \\
\text { positive information } \\
- \text { There are NU female figures voicing gender justice }\end{array}\end{array}$ & $\begin{array}{l}\text { Even though it contradicts } \\
\text { religious values, Muslimat NU can accept } \\
\text { leadership pomen }\end{array}$ \\
\hline
\end{tabular}

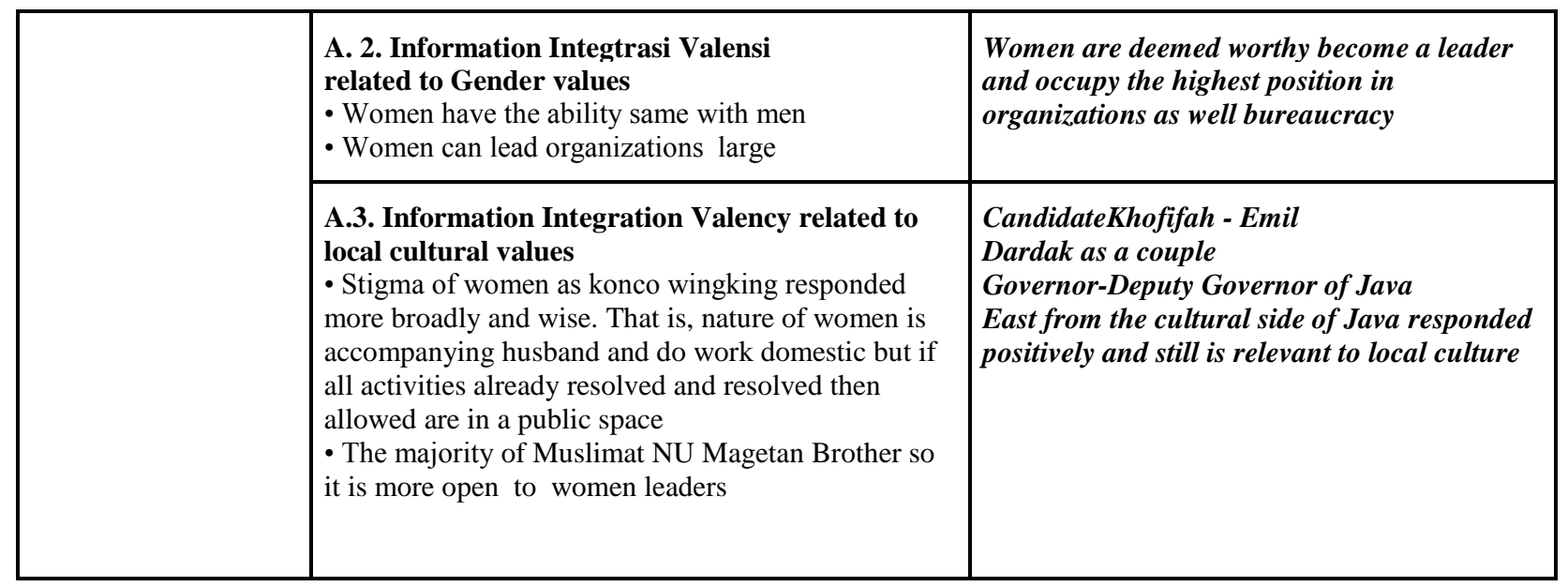




\begin{tabular}{|c|c|c|}
\hline \multirow[t]{3}{*}{$\begin{array}{l}\text { B. Weight of } \\
\text { Assessment }\end{array}$} & $\begin{array}{l}\text { B.1. Assessment based on Track Record } \\
\text {-Khofifah's experience in the lead organization } \\
\text { - Khofifah is part of the bureaucracy. }\end{array}$ & $\begin{array}{l}\text { Credibility is an issue importantin delivery } \\
\text { information in progress communication. }\end{array}$ \\
\hline & $\begin{array}{l}\text { B.2. Assessment based on political ability } \\
\text { - Presentation of one's self to be important, especially } \\
\text { regarding a person's communication figures before } \\
\text { the public } \\
\text { - Performance description through Vision and } \\
\text { Mission } \\
\text { - Khofifah's communication skills are good and } \\
\text { delivered in a simple way that easy to understand } \\
\text { the constituents. In delivery of communication } \\
\text { programs the language is sometimes inserted in } \\
\text { politics area }\end{array}$ & $\begin{array}{l}\text { KCapacity of politics capable influence } \\
\text { voters in make a choice and can Positive } \\
\text { values boost the candidate pemimpin }\end{array}$ \\
\hline & $\begin{array}{l}\text { B.3. Assessment based on style communication } \\
\text { - Owned experience Khofifah became proving } \\
\text { performance and delivering beliefs about abilities run } \\
\text { the promised program. } \\
\text { - Khofifah performance program information } \\
\text { penetrates social media }\end{array}$ & $\begin{array}{l}\text { Communication style determines contituent } \\
\text { beliefs against the decision to choose leader }\end{array}$ \\
\hline
\end{tabular}

\begin{tabular}{|l|l|l|}
\hline & $\begin{array}{l}\text { B.4. Assessment of gaps that appear } \\
\text { - Muslimat NU still cling firmly against religious law } \\
\text { but also can open and receive other information } \\
\text { - Muslimat NU respects everything that Kyai } \\
\text { delivered but deep determine only in hand each } \\
\text { - The gap between valence and weight the assessment } \\
\text { brings out the negotiations information }\end{array}$ & $\begin{array}{l}\text { Ketimpanganarising from the backward } \\
\text { between the valence with assessment } \\
\text { weight in interpret the leader pomen }\end{array}$ \\
\hline $\begin{array}{l}\text { C. Negotiations } \\
\text { Information }\end{array}$ & $\begin{array}{l}\text { C.1. Private Negotiation } \\
\text { These private negotiations are based on the } \\
\text { knowledge the informant has mengnai candidates } \\
\text { who run in political competition } \\
\text { - Although psychologically women considered weak } \\
\text { but female considered capable of being a leader of }\end{array}$ & $\begin{array}{l}\text { pits choice natural based on knowledge } \\
\text { pemingmant regarding candidates }\end{array}$ \\
\hline
\end{tabular}

\section{C.2. Group Negotiation}

-Build deep political stability effort Khofifah's

victory as Governor East Java through

organizational support Muslimat NU

-The solidarity of Muslimat NU in provide embodied support in the grand campaign, there is Warung NU and routine recitation that is inserted Khofifahprogram information for

\section{Dgroup support immensely needed in} building political stability

\section{Discussion}

This is to find out how the integration of information on Muslimat NU in Magetan Regency choosing Khofifah Indar Parawangsa as Governor of East Java is based on the theory of integration Information according to littlejhon \& Foss, 2009. Where is the effect of changing attitudes a person depends on two things: 


\section{1) Valence}

In connection with the NU Muslimat's assessment of the Khofifah leadership based on on religious values, gender values and local culture.

2) Rating Weight

In connection with the NU Muslimat's assessment of the leadership of the Khofifah which is based on Track records, political skills, communication styles, and gaps that emerge from research can be drawn the results that the Research Weight has a high value compared to valensi. Which means that Muslimat NU prioritizes the weight of Khofifah's assessment as a leader compared to the existing valence values.

Meanwhile, to find out the negotiation information used by Muslimat NU Magetan Regency in choosing Khofifah Indar Parawangsa as Governor of East Java based on Swann's Negotiation Theory, 2005. Where the negotiation process is carried out to make justification of thoughts and understanding of someone so as to produce identity which is acceptable. Social stability is also needed to strengthen and reinforce positions his identity. In this case, it relates to the alignment of the valence and weight ratings Muslimat NU towards Khofifah leadership. Negosiasi NU's done in private and group.

- Private negotiations are based on the personal knowledge of Muslimat NU Khofifah as a woman leader.

- Group negotiations are based on knowledge within the NU and Muslimat Group the efforts made by the group to build its political stability.

\section{Closing}

\section{A. Conclusion}

1. Muslimat NU of Magetan Regency in choosing Khofifah Indar Parawangsa as The Governor of East Java can accept women's leadership. This is because of them prioritizes the weight of the assessment based on track record, ability politics, communication style, and the gap that appears compared to good valence values religion, gender and local culture in society.

2. Muslimat NU of Magetan Regency in choosing Khofifah Indar Parawangsa as The Governor of East Java conducted negotiations individually and in groups. Where, in personal negotiation of the choice is based on the knowledge of the informants regarding potential leaders whereas group negotiations are based on support and things what groups do in an effort to build political stability.

\section{B. Advice}

Based on research, to become a woman leader, it is better pay attention to matters relating to the weight of the assessment based on the track record, political skills, communication styles and the gaps that will emerge. aside from that should consider the negotiations that the voters will undertake. The costs are based The keywords or characteristics of the negotiations used in accordance with Swann's theory are:

1. The leader must have the opportunity or opportunity to run in the election general 2. Convey signs and symbols of oneself that make its constituents sure to choose it 3 . There is a support system / support from the environment who is always helpful winning 4. A leader should have good credibility and always increase their abilities 5. Always maintain an image to build opinions and other people's attention to themselves from the research above, it can produce strategies that can be used by 
prospective leaders especially women to be able to compete in future democratic parties. Among them are: 1. A candidate for leadership, especially women, must have credibility high self in education, career, political experience, internal position organization, etc. All must be able to create a self-image that the candidate is worthy of being leader 2 . In addition, the communication style of the prospective leader should be understood and understood be understood by voters by using any media 3 . Prospective leaders are required to upgrade their abilities so that they are voters feel the leader they choose matches their expectations 4. Leaders who both should take care of their image wherever it is in order to maintain assumptions and attention of voters. This is expected to create harmony between realities social with the concept of a person. And the ultimate goal of support systems between the constituents and leaders remains awake.

\section{Bibliography}

Ali,Novel, 1999.Peradaban Komunikasi Politik. Bandung: Remaja Rosdakarya Arifin, Hamid Representasi Perempuan dalam Pers, Jurnal Komunikasi Massa, Vol. 1, No. 1, Juli 2007, Jurusan Ilmu Komunikasi FISIP UNS

Ardial,2010 Komunikasi Politik Jakarta Barat: PT Indeks

Bogdan, Robert \& Tylor, Steven. J. 1992.Pengantar Metode Penelitian Kualitatif. Surabaya: Usaha Nasional

Budiardjo, Miriam.1998. Partisipasi dan Partai Politik: Sebuah Bunga Rampai. Jakarta: Yayasan Obor Indonesia.

Budiardjo, Miriam, 1985. Dasar-Dasar Ilmu Politik, Jakarta: Gramedia Pustaka Utama Creswell. John.W. 2014. Research Design: Pendekatan Kualitatif, Kuantitatif dan Mixed.Yogyakarta : Pustaka Pelajar.

Fatimah, Siti, Kampanye sebagai Komunikasi Politik : Esensi dan Strategi dalam Pemilu, dalam jurnal Resolusi Vol. 1 No. 1 Juni 2018

Gaffar, Affan, 1997. Menampung partisipasi Politik Rakyat, JSP, Yogyakarta: Gadjah Mada University press.

Kurebwa, Jeffrey, Political Participation of Rural Women in Decision-Making at the Local Government Level in Zimbabwe, International Journal of Education, Culture and Society. Vol. 1, No. 2, 2016, pp. 33-43. doi: 10.11648/j.ijecs.20160102.12

Littlejohn, Stephen W. dan Foss, Karen A. 2011. Theories of Human Communication (tenth edition). Illinois: Waveland Press, Inc

Lovenduski, Joni, 2005. Politik Berparas Perempuan,Yogyakarta: Kanisius

Handoko, Rudy, Mengapa Partisipasi dan Peran Politik Perempuan Rendah, http://wikimu.com Mas'oed, Mohtar \& Dr. Colin MacAndrews. Ed.1995 Perbandingan Sistem Politik, Yogyakarta: Gadjah Mada University Press

Mulyana, Deddy \& Solatun,2007. Metode Penelitian Komunikasi: Contoh Contoh Penelitian Kualitatif dengan Pendekatan Praktis. Bandung, PT. Remaja Rosdakarya

Mukafi Niiam, Ahmad dalam https://www.nu.or.id/post/read/101933/muslimat-nu-soko-guru-nahdlatul ulama-, diakses 10 September 2019 
Nimmo, Dann .1989. Komunikasi politik, khalayak dan efek, Bandung: Remaja Karya. Nimmo, Dann. 2004.Komunikasi Politik: Khalayak dan Efek, Remaja Rosda Karya, Bandung, Nadezhda Shvedova, Obstacles to Women's Participation in Parliament, Women in Parliament: beyond

Numbers, International IDEA Women in Politics, http://archive.idea.int/ women/parl/ Neuman, WL 2003. Social Research Methods: Qualitative and Quantitative Approach.Boston: Allyn and Bacon

Pawito,, 2009. Komunikasi politik: Media Massa dan Kampanye Pemilihan, Yogyakarta: Jalasutra Pawito. (2007). Penelitian Komunikasi Kualitatif. Yogyakarta: Pelangi Aksara Yogyakarta Patton, Michael Quinn. 2002 Qualitative Research and Evaluation Methods. New York: Sage Publication

Saeful Muhtadi, Asep. 2008 Komunikasi Politik Indonesia: Dinamika Islam Politik PascaOrde Baru, Bandung: PT Remaja Rosdakarya

Sugiyono. 2015. Metode Penelitian Pendidikan (Pendekatan Kuantitatif, Kualitatif dan R\&D). Penerbit CV. Alfabeta: Bandung

Snape,D \& Spencer, L.2003. The Foundations of Qualitative Research, in Ritchie, J \& Lewis, J (ed ). Qualitative Research Practice: A Guide for Social Science Student \& Reseacher. London: Sage Publication

Swann, William B. The Self and Identity Negotiaton. John Benjamins Publishing Company. Jornal. Interaction Studies 6:1, 69-83, 2005

Swann, WB Jr.1983. Self-Verification: Bringing social reality into harmony with the self. In J Suls\&A.G. Greenwald(Eds), Psychological prespestives on the self, vol 2, pp.33-66), Hillsdale, NJ: Erlbaum

Swann, WB Jr. 1981. Self-verification processes: How we sustain our self-conceptions. Jurnal of Experimental Social Psycology,17,351-372

Tanzeh A. \& Suyitno. (2006). Dasar-Dasar Penelitian. Surabaya: eLKAF

Uchjana Effendy, Onong, 2006. Ilmu Komunikasi: Teori dan Praktek. Bandung : PT. Remaja Rosdakarya.

Umar, Nazaruddin, Perspektif Jender Dalam Islam, Jurnal Pemikiran Islam PARAMADINA, http://media.isnet.org/islam/Paramadina/Jurnal/Jender

Venus, Antar (2007) . Manajemen Kampanye.Bandung: Simbiosa Rekatama Media Zeng, Benxiang (2014). Women's Political Participation in China: Improved or Not?. Journal of International Women's Studies, 15(1), 136-150. Available at: https://vc. bridgew. edu/ jiws /vol15/ iss1/9

https://www.eajournals.org/journals/global-journal-of-political-science-and-administration-gjpsa/vol-6issue-5-october-2018/political-participation-and-gender-inequality-in-nigerian-fourth-republic/ http://romeltea.wordpress.com/2007/08/25/komunikasi-politik/

http://theconversation.com/elektabilitas-perempuan-di-pilkada-2018-meningkat-101179http://thecon versation.com/elektabilitas-perempuan-di-pilkada-2018-meningkat-101179 https://www.cnnindonesia.com/pilkadaserentak/nasional/20180707181820-32-312332/kpu-khofifah - emil -menang-pilgub-jatim-unggul-1-juta-suara?. diakses 7 September 2019.

http://www.kompas.com 
https://surabaya.tribunnews.com/2018/05/06/gerilya-sukseskan-khofifah-muslimat-magetan-bentuk tim-untuk-door-to-door.

https://kowani.or.id/muslimat-nu/

https://www.tandfonline.com/doi/full/10.1080/00344893.2018.1438306

https://www.journalijdr.com/women-empowerment-study-political-participation-women-surat,

\section{Copyrights}

Copyright for this article is retained by the author(s), with first publication rights granted to the journal.

This is an open-access article distributed under the terms and conditions of the Creative Commons Attribution license (http://creativecommons.org/licenses/by/4.0/). 